\title{
Effect of honeybee pollination on seed and fruit yield of agricultural crops in Ethiopia
}

\begin{abstract}
Pollination is a critical link in the functioning of ecosystems, and it improves the yield of crops. Insect pollination is an essential input in the production of crops grown worldwide. Of the approximately 300 commercial crops about $84 \%$ are insect pollinated. Honeybees are responsible for $70-80 \%$ of insect pollination. This indicated how much honeybees are the most efficient insect pollinators of cultivated crops and wild flora in agricultural systems. The main reason is that honeybees are abundant and widespread everywhere. They have well developed mechanism of communication to exploit their environment. The value of additional yields obtained by pollination service rendered by honeybees is 15-20 times more than the value of all hive products put together. Studies conducted in Ethiopia have also proven the role of honeybee pollination in improving the yield and quality of some crops such as Malus sylvestris (apple), Allium cepa (red onion), Guizotia abyssinica (niger) and Vicia faba (faba bean). The yield increment was varied from $33.5-84 \%$ among the above crops due to honeybee pollination. However, unwise pesticide applications become the main problem for some crops in Ethiopia. This is due to, low level understanding of the value of pollination on the yield of agricultural crops. Therefore, attention should be given for the legal protection of honeybees and other insect pollinators; especially, protecting the honeybees from pesticide poisoning, developing pollinators' conservation policy, the idea of crop pollination should be included in national crop production strategic plan and awareness creation should be given to the society about the value of crop pollination.
\end{abstract}

Volume 4 Issue 5 - 2019

\author{
Tura Bareke,Admassu Addi \\ Holeta Bee Research Center, Oromia Agricultural Research \\ Institute, Ethiopia
}

\begin{abstract}
Correspondence: Tura Bareke, Holeta Bee Research Center, Oromia Agricultural Research Institute, Ethiopia, Tel 2510920287173, Email trbareke@gmail.com
\end{abstract}

Received: August 08, 2019 | Published: September 27, 2019

Keywords: pollination, honeybee, yield, crops, pesticide

\section{Introduction}

Pollination is an essential ecosystem service that enables plant reproduction. More than $75 \%$ of leading food crops depends on animal pollinators.$^{1,2}$ Of the approximately 300 commercial crops, about $84 \%$ are insect pollinated. ${ }^{3,4}$ Among these honeybees are substantially important in world's agricultural economy, in that $35 \%$ of the world's food production relies on pollinators, of which the honeybee accounts for $70-80 \%$ which is the largest portion..$^{1,5,6}$ This is attributed to the body structures, social and instinctive behavioral characteristics of the honeybee. Honeybees are regular visitors of the flowers to be pollinated. They can visit many flowers and plants per unit time. As well as honeybees have a well-developed communication system that enables individual bee to be alerted to the needs of the colony and to the location of suitable food source. The pollinating potential of a single honeybee colony becomes evident when it is recognized that its bees make up to 4 million trips per year and that during each trip an average of about 100 flowers are visited. ${ }^{7}$ These indicates that pollen or nectar gatherers spend much less time at each flower, ${ }^{8}$ which means that they visit more flowers per unit of time, thereby increasing their effectiveness as pollinators. These extraordinary activities of the honeybee play an important role in its function as a successful insect pollinator. The value of additional yields obtained by pollination service rendered by honeybees is $15-20$ times more than the value of all hive products put together (Kaloo, 2040 as cited in Kurukshetra, 2017).

The vast forest area and mountains of Ethiopia hosts a large number of honeybee (Apis mellifera) colonies. ${ }^{9,10}$ Hence, honeybee has a great potential in raising the productivity of cross-pollinated as well as other crops those need insects for their pollination.

Many farmers in Ethiopia invest in fertilizers, pest control, crop rotation and other management activities. ${ }^{11,12}$ However, the role of crop pollinators in crop pollination is totally neglected by crop growers of Ethiopian. ${ }^{13}$ Unfortunately, both managed honeybees and wild pollinators have been contributing on raising the productivity of crops without the knowledge of growers. ${ }^{10}$ Accordingly, the Economic value of pollinators for some agricultural crops was estimated to be 815.2 million dollar in Ethiopia. ${ }^{14}$ In the absence of the pollinators, this value may drop by $16 \%$.

In general, a lot of crops are benefited from honeybees worldwide in general and particularly, in Ethiopia. Some of them are listed below: From oil crops Guizotia abyssinica (niger), Linum usitatissimum (talba), Brassica carinata (rafu), Carthamus tinctorius (Suf), Sesamum indicum (Salit) and Arachis hypogea (groundnut); pulses Vicia faba (faba bean), Medicago sativa (alfalfa), Lathyrus sativus, and Cicer arietinum (chick pea), Pisum sativum (pea), Lentis culinaris (misir) and horticultural crops Malus sylvestris (apple), Allium cepa (red onion), Citrus aurantium (orange), Citrus aurantifolia (lomi), Carica papaya (papaya), Mangifera indica (mango), Persea americana (avocado), Coffea arabica (coffee), Citrullus lanatus (watermelon), Lycopersicon esculentum (Tomato). ${ }^{9}, 10,14-17$

The effect of pollination on yield and quality of niger, onion, apple, and faba bean seeds have been reported, ${ }^{15-17}$ showing that honeybee pollination plays a great role in the Ethiopian crop production. Managing honeybees for crop pollination have a significant role 
for the improvement of agricultural crop yield in terms of quality and quantity. Thus, the main aim of this review paper is to provide information about the role of honeybee pollination on the yield of niger, onion, apple, and faba bean, and the main challenges to pollination in Ethiopia and to indicate future direction.

\section{Honeybee pollinated crops in Ethiopia}

Although pollination research in Ethiopia is at infant stage, few studies have been conducted on some of the agricultural crops such as: Niger, onion, apple, and faba bean.

Guizotia abyssinica (Niger): It is one of the oilseeds crop grown in Ethiopia. It has an extremely low harvest index due to shattering. Inputs such as fertilizer promote vegetative growth rather than increase seed yield $\left({ }^{8,18}\right.$ Niger is self-incompatible crops that required honeybees and other insects' cross-pollination. It provides both nectar and pollen for insect pollinators, especially for honeybees. ${ }^{9}$ Because of this rewards, it is highly visited by honeybees.

The effect of honeybees as pollinator on niger seed yield, oil content and germination capacity was tested by many authors. Accordingly, seed yield increment ranging from $43-80 \%$ has been obtained. Around Holeta (Central Ethiopia) the maximum seed yield was $600 \mathrm{~kg}$ hectare ${ }^{19,2} 0$ using honeybees as pollinator of niger; while $16700 \mathrm{~kg} /$ hectare was obtained in Tigray, Northern Ethiopia. ${ }^{16}$ This yield differences between Central and Northern Ethiopia have recorded because of agroecology, soil type variation, and other environmental factors. On the other hand, the higher yield of niger caged with honeybees might be due to the higher pollination efficiency of the honeybees inside the cage. ${ }^{16}$ Study conducted in India by Rao and Suryanarayana ${ }^{21}$ also reported three times higher yield in plots caged with honeybees as compared with plots caged without honeybees. In addition to seed yield increment honeybee pollinated plots have higher percentage of oil content and better germination performance. ${ }^{19}$ This indicated how much honeybees are contributing to seed yield increment of niger (Figure 1).

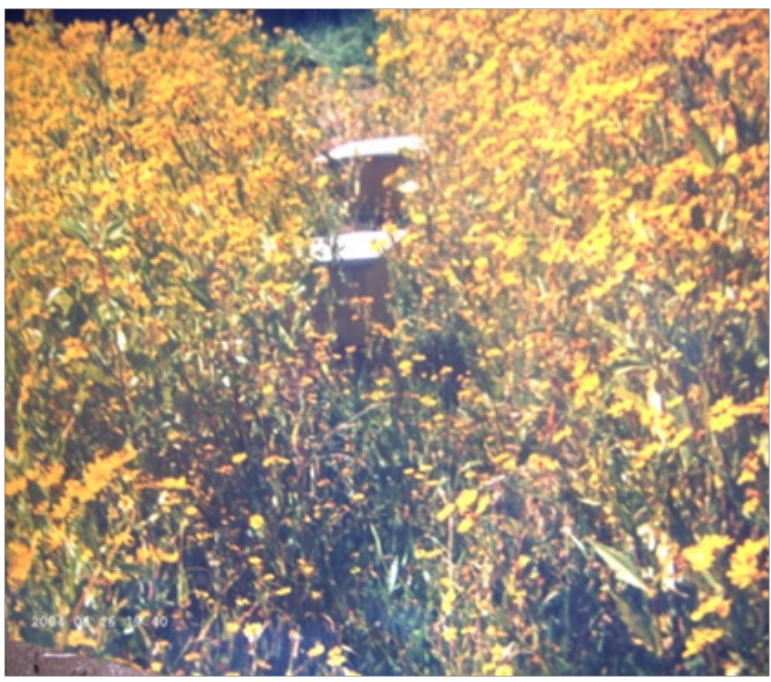

Figure I Honeybee hive into the niger crop for pollination.

Allium cepa (Red onion): It is one of the important condiment and vegetable crops grown in Ethiopia. In Ethiopia, the production and productivity of the red onion is far below the world average despite to its year-round production scenarios. ${ }^{22}$ This low yield results indicate that the presence of a huge gap in production and productivity at the country because of the absence of improved cultivars, application of inappropriate agronomic practices and limited attention/awareness on the benefits of intensive production. In addition to this, there is lack of knowledge to consider pollination as agronomic input for red onion production.

Inadequate pollination of the onion results low seed yield and low germination capacity. ${ }^{15}$ Wind has little effects on onion pollination because of sticky pollens. Although other insects and solitary bees have importance on onion pollination; honeybees are the most valuable ones. Onion flowers have ample nectar and pollen. That is why onion flowers are so attractive for honeybees (Figure 2).

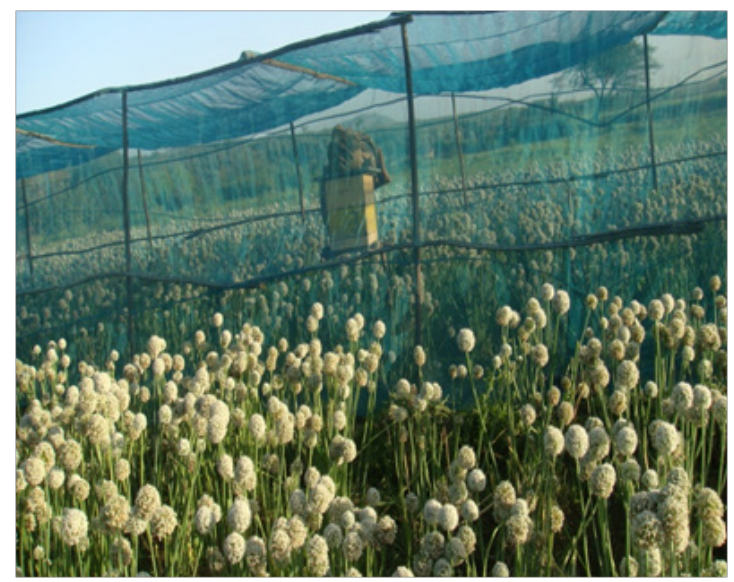

Figure $\mathbf{2}$ Honeybee hive into the onion crop covered in a cage for pollination.

In Ethiopia the effect of honeybee pollination on seed yield of onion had been estimated. Study conducted by Admassu et al. ${ }^{15}$ showed that the yield obtained from the plots caged with honeybee pollination was the highest with the mean yield of $17500 \mathrm{~kg} /$ hectare followed by plots left open under a natural condition with the mean yield of $10000 \mathrm{~kg} /$ hectare. The lowest mean yield $(500 \mathrm{~kg} /$ hectare) was recorded for the plots excluded insect pollinators. With regard to 1000 seed weight, there was no significant difference in all treatments. The seed yield increment ranging from $41-84 \%$ has been obtained. This indicated how much honeybees are contributing to seed yield increment of this valuable crop. The study conducted by Prashant et al. ${ }^{23}$ in India also confirmed that the high proportion of honeybees, compared to other insects visiting the flowers, indicated that honeybees were the major pollinators of the red onion crop at our field site, with both honeybee abundance and seed yield and quality increasing proportionally. Yucel and Duman ${ }^{24}$ reported that the germination rate was greater on average by $12 \%$ in red onion with honeybee activity.

Apple (Malus sylvestris): It is one of the cash and high-value crop in highlands of the Ethiopia. Apple production is expanding in most highlands of Ethiopia at level of smallholder farmers. However, the production in quantity and quality of fruit yield was low in the absence of honeybee pollination. Most apple varieties are self-incompatible and need insect pollination; especially honeybee pollination., ${ }^{2,17,25}$ Hence, integration of honeybee with apple orchard is important to boost the quality and quantity of fruit yield. Study conducted by Tura et al. ${ }^{17}$ indicated that honeybee pollination increases the yield of marketable apple fruit yield by $50 \%$ and improve fruit yield increment by $45.5 \%$ due to honeybee pollination. The average marketable apple fruit yield per individual tree is $3.2 \mathrm{~kg}$, if caged with honey bees, and 
$2.2 \mathrm{~kg}$ for trees, open to all insect pollinators. Thus, if an individual apple farmer would have 100 trees that are supplied with honeybees during the flowering season; a total marketable apple fruit yield of $320 \mathrm{~kg}$ is expected. In comparison, the total production from the same tree population is estimated to be $220 \mathrm{~kg}$ if providing free access to all insect pollinators. By introducing honeybee colonies to apple orchards of ANNA variety and by maintaining other management practices such as weeding, watering and pest control constant, the total annual yield increment for this individual grower is $100 \mathrm{~kg}$ per 100 trees. If a kilogram of apple would be valued 40 Ethiopian Birr (ETB), the total financial loss of each grower, by not using honeybees as pollinators, is $4,000 \mathrm{ETB}$ per 100 apple trees. Although there is yield record for honeybees, flies and butterflies are also considered to be the major insect pollinators, next to honeybees for apple flowers. ${ }^{17}$

Study conducted by Partap et al. ${ }^{26}$ in Pakistan also indicated that supplementary pollination by honeybees' enhanced fruit set by $12 \%$ to $14.5 \%$, and reduced premature fruit drop by $0.5 \%$ to $7.6 \%$. It enhanced the overall fruit yield by $44.9 \%$. In addition to this, the honeybee pollination also enhanced the quality (weight, shape and colour) of apple fruit. Fruits from honeybee-pollinated orchards were bigger and weighed more compared to those from control orchards. The average weight of an apple fruit in honeybee pollinated apple orchard was $190.7 \mathrm{~g}$, as compared to $149 \mathrm{~g}$ in control orchard, revealing $28.25 \%$ increase in fruit weight as a result of honeybee pollination (Figure 3).
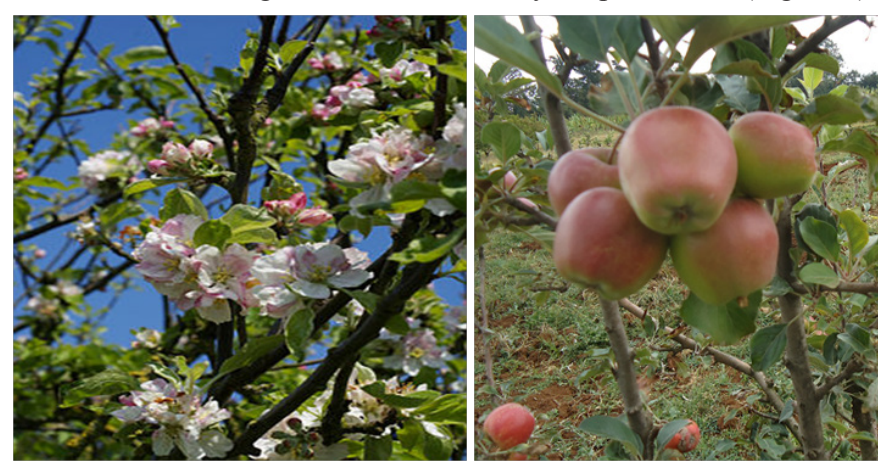

Figure 3 Apple flowers and fruits.

Faba bean (Vicia faba): Faba bean is one of the most important pulse crops in Ethiopia and stands first among the highland pulses. In Ethiopia faba bean grows mainly for human consumption, as it is an important protein source in the diet of the poor. ${ }^{27} \mathrm{It}$ is an allogamous, or have a mixed mating system with both self- and cross-pollination. ${ }^{28}$ Inadequate pollination is a major constraint to the potential yields of faba bean crops. It has heavy and sticky pollen that cannot be released into the air. Thus, faba bean cross-pollination demand insect pollinators for the transferring of pollen grain from a flower to another flower. Honeybees are the main insect pollinators of faba bean. Admassu (unpublished data) reported that pollinating faba bean using honeybees increased the crop yield by $33.5 \%$. The study conducted in Central Sudan by Gasim and Abdelmula ${ }^{29}$ also reported that the average improvement in number of seeds per pod due to honeybee pollination was $26 \%$ and the relative improvement in number of pods/plant in the presence of honeybees was $20 \%$. According to Gasim and Abdelmula, ${ }^{29}$ the overall average improvement of faba bean in performance due to the honeybee pollination was $22 \%$ which is similar to the other studies comparing faba bean performance in controlled conditions with and without insect pollinators $25 \%{ }^{30}$ and $26 \%$ (Figure 4). ${ }^{31}$
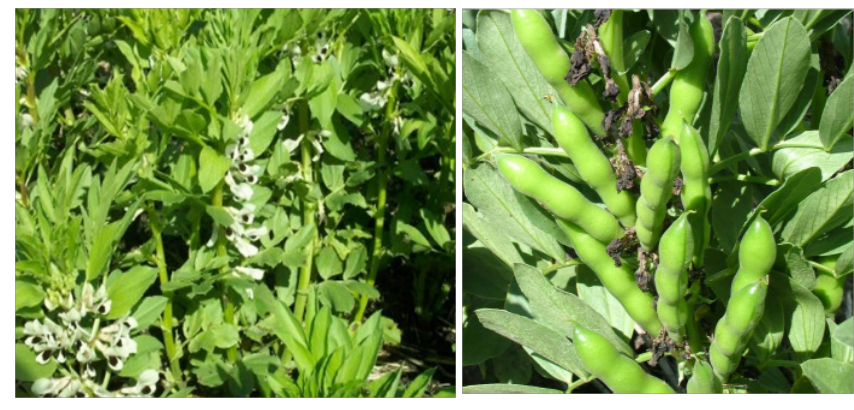

Figure 4 Flowers and fruits of faba bean.

\section{Challenges of honeybee pollination}

Various causes of honeybee's decline have been reported throughout the world due to, degradation of habitats; unwise application of pesticide and climate change. ${ }^{32}$ Even though there is no concrete information about honeybee decline in Ethiopia, reports from the different stakeholders indicated that there was a decline of honeybee colonies due to pesticide application and deforestation. The clearing of forest and bushes in Ethiopia have a significant impact on honeybee population and its species richness. ${ }^{33}$ The habitat shrinkage not only affects the honeybee abundance but also can cause scarcity of bee forages which is detrimental for survival and honey production. ${ }^{34}$

Currently, there is increasing compromise that pesticides have significant impact on honey production in Ethiopia; ${ }^{35}$ due to pesticide application problem, poor seed set of onion, the death of honeybees in the hives and abandoning of beekeeping. There are different pesticides used by crop growers in Ethiopia which can poison the honeybees and influencing the bee health. The most widely used brands of pesticides in Ethiopia were Malathion $50 \%$, penetrate $50 \%$, Ethiothoate $40 \%$, Agrothoate 40\%, Diazion60\% EC, Dimethoate 40\% EC, Ethiolathion $50 \%$ and herbicides like 2,4-D. Due to misapplication of these chemicals, honeybee mortality and causing reduction of honeybee colonies, which eventually results in a reduction of bee products and crop yield. ${ }^{36}$ On the other hand, lack of awareness creation about the value of crop pollination is another key factor to do more on this area.

\section{Conclusion}

Pollination is an important ecosystem services and honeybee is valuable pollinator. It has a great adaptive capacity, as it is found almost everywhere in diverse climates. Honeybee pollination improve the yield of the yield of red onion, niger, apple and faba bean. However, unwise use of pesticides application affect the integration of beekeeping and crops. Unwise application of pesticides during the flowering period of target crops should be avoided and to ensure the protection of honeybee health. Farmers should use ecofriendly pesticides or organic pesticide derived from plant extract and integrated pest management practice should be promoted for control of pests in their agriculture field. However, low level understanding of the value of pollination is affecting the yield of agricultural crops. Therefore, a lot has to be done on the contribution of honeybee and other insect pollinators in boosting crop yield and to solve the challenges they are facing.

\section{Future direction}

a. The idea of crop pollination should be included in national crop production strategic plan for all pollinators dependent crops 
b. Awareness creation should be given to the society about the value of crop pollination Attention should be given for the legal protection of honeybees and other insect pollinators; especially, protecting the honeybees from pesticide poisoning.

c. Developing pollinators conservation policy

\section{Acknowledgments}

We would like to acknowledge all previous investigators who produced valuable research articles for the analysis review.

\section{Funding}

None.

\section{Conflicts of interest}

The authors declare that there is no competing of interest.

\section{References}

1. Klein AM, Vaissière BE, Cane JH, et al. Global pollinator decline: a literature review. Ecology for a crowded planet, Science. 2007;304:12511252 .

2. Khalid AK, Khawer JA, Asif R, et al. Pollination effect of honey bees, Apis mellifera L. (Hymenoptera: Apidae) on apple fruit development and its weight. Persian Gulf Crop Protection. 2012;1(2):1-5.

3. Richards KW. Non-Apis bees as crop pollinators. Rev Suisse Zool. 1993;100:807-822.

4. Williams IH. Aspects of bee diversity and crop pollination in the European Union. In: Matheson A, Buchmann SL, O'Toole C, et al, editors. The Conservation of Bees. New York: Academic Press; 1996:63-80.

5. Greenleaf SS, Kremen C. Wild bees enhance honey bees' pollination of hybrid sunflower. Proc Natl Acad Sci USA. 2006;103:13890-13895.

6. Winfree R, Williams NM, Dushoff J, et al. Native bees provide insurance against ongoing honeybee losses. Ecol Lett. 2007;10(11):1105-1113.

7. Free JB. Insect pollination of crops. 2nd ed. London, UK: Academic press; 1993.

8. Sharma HK, Gupta JK, Thakur JK. Pollination studies on apple and pear. Chiang Mai, Thailand: Proceedings of the Seventh International Conference on Tropical Bees: Management and Diversity and Fifth Asian Apicultural association Conference; 2001:275-280.

9. Fichtl R, Admasu A. Honey bee flora of Ethiopia. The National Herbarium, Mergaf Verlag, Germany: Addis Ababa University and Deutscher Entwicklungsdieenst; 1994. 510 p.

10. Admassu A, Kibebew W, Amssalu B, et al. Honeybee forages of Ethiopia. Addis Ababa: United Printers; 2014.

11. Amera T, Abate A. An assessment of the pesticide use, practice and hazards in the Ethiopian rift valley. , UK: Pesticide action network; 2008;11-32.

12. Bizuayehu Alemu. Practices, challenges and prospects of agricultural land management in Machakel Woreda, East Gojjam Zone, Ethiopia. Department of Natural Resources and Environmental Management, Ethiopia: Addis Ababa University; 2014. 40 p.

13. Misganaw M, Mengesha G, Awas T. Perception of farmers on importance of insect pollinators in Gozamin District of Amhara Region, Ethiopia. Biodiversity International Journal. 2017;1(5):1-7.

14. Getachew WA. Economic value of pollination service of agricultural crops in Ethiopia: biological pollinators. Journal of Apicultural Science. 2018;62(2):265-273.
15. Admassu A, Gizaw E, Amssalu B, et al. The effect of honeybee pollination on seed yield of Allium cepa. Journal of Ethiopian Society of Animal Production. 2006;6(4):79-73.

16. Haftom G, Alemayehu T. Effect of honeybee (Apis mellifera) pollination on seed yield and yield parameters of Guizotia abyssinica (L. f). African Journal of Agricultural Research. 2014;9(51):3687-3691.

17. Tura B, Admassu A, Kibebew W. Role and economic benefits of honey bees' pollination on fruit yield of wild apple (Malus sylvestris (L.) Mill.) in Central Highlands of Ethiopia. Bee World. 2018;95(4):113-116.

18. Getinet A, Sharma SM. Niger. Guizotia abyssinica (L. f.) Cass. Promoting the conservation and use of underutilized and neglected crops. 5. Institute of Plant Genetics and Crop Plant Research, Rome: Gatersleben/International Plant Genetic Resources Institute; 1996.

19. Admassu A, Nuru A. Effect of honeybee pollination on seed yield and oil content of Niger (Guizotia abyssinica). Proceedings of the First National Conference of Ethiopian Beekeepers Association, Addis Ababa, Ethiopia; 2000:67-73.

20. Admassu A, Tura B, Kibebew W, et al. Participatory evaluation on the effect of honeybee pollination on Niger (Guizotia abyssinica) seed yield in West Shoa Zone. In: Gemechis L, Kibebew W, Amssalu B, et al, editors. Apiculture research achievements in Ethiopia. Oromia Agricultural Research Institute, Holeta, Ethiopia: Holeta Bee Research Center; 2012. $50 \mathrm{p}$.

21. Rao GM, Suryanarayana MC. Studies on the foraging behavior of honeybees and its effect on the seed yield in Guizotia abyssinica. Indian Bee J. 1990;52(4):31-33.

22. FAO. Major food and agricultural commodities and producers countries by commodity. United Nations; Food and Agriculture Organization; 2012.

23. Prashant BS, Jagtap PK, Patel MC, et al. Seed yield increase in niger crop in to relation to honeybee and other pollinators. Cercetări Agronomice in Moldova. 2017;1(2):73-81.

24. Yucel B, Duman I. Effects of foraging activity of honeybees (Apis mellifera L.) on onion (Allium cepa) seed production and quality. Pak $J$ Biol Sci. 2005;8(1):123-126.

25. Delaplane KS, Mayer NF. Crop pollination by bees CABI publishing, Wallingford; 2000.

26. Partap U, Hussain S, Hussain E, et al. Honeybee pollination and apple yields in Chitral, Pakistan. ICIMOD Working Paper 2017/19. Kathmandu: ICIMOD; 2017.

27. Keneni G, Musa J. Review of Faba bean (Vicia faba) Genetics and breeding Research in Ethiopia Progresses and Lesson of a decade Paper presented to $2^{\text {nd }}$ National workshop on food and forage Legumes in Ethiopia, 22-26 September, Addis Ababa, Ethiopia; 2003.

28. Free JB. Insect pollination of the crops. London; 1970. $544 \mathrm{p}$.

29. Gasim SM, Abdelmula AA. Impact of bee pollination on yield of faba Bean (Vicia faba L.) grown under semi-arid conditions. Agricultural Sciences. 2018;9:729-740.

30. Somerville DC. Honeybees (Apis mellifera L.) increase yields of faba beans (Vicia faba L.) in New South Wales while maintaining adequate protein requirements from faba bean pollen. Australian Journal of Experimental Agriculture. 1999;39:1001-1005.

31. Algiaamdi A, Algamdi S. The impact of insect pollination on yield and yield components' of faba Bean (Vicia faba L.). Saudi Journal of Biological Science. 2003;10:56-63.

32. Kearns CA, Inouye DW. Pollinators, flowering plants, and conservation biology, much remains to be learned about pollinators and plants. Bioscience. 1997;47:297-366. 
33. Aizen MA, Garibaldi LA, Cunningham SA, et al. How much does agriculture depend on pollinators? Lessons from long-term trends in crop production. Ann Bot. 2009;103(9):1579-1588.

34. Klein AM, Steffan-Dewenter I, Tscharntke T. Rain forest promotes trophic interactions and diversity of trap-nesting Hymenoptera in adjacent agroforestry. Journal of Animal Ecology. 2006;75:315-323.
35. Kerealem E, Tilahun G, Preston TR. Constraints and prospects for apiculture research and development in Amhara region, Ethiopia. Livestock Research for Rural Development. 2009.

36. Bezabeh A. Toxicity effects of commonly used agrochemicals to Ethiopian honeybees. Holeta: Holeta Bee Research Center; 2010. 13 p. 